\title{
Teaching Natural Sciences using the TheoPrax Method Doubles Learning Effectiveness
}

\author{
${ }^{1}$ Doerthe Krause, ${ }^{1}$ Peter Eyerer, ${ }^{2}$ Safi Baborie, ${ }^{1}$ Martina Parrisius \\ ${ }^{1}$ Fraunhofer Institut für Chemische Technologie ICT, Germany \\ ${ }^{2}$ Furtwangen University (HFU), Germany
}

\begin{abstract}
Based on the scientific results new teaching methods and principles are needed to save knowledge in our longterm memory. On the other hand the self-motivation of the learners should be increased and the learningeffectiveness improved, e.g. by interaction of brain and hand. This means a merge of theory and practice $=$ TheoPrax. In schools the TheoPrax method, which was first introduced at the 'Fraunhofer Institute for Chemical Technology' (ICT) in Pfinztal, Germany 1996, is applied project-based in cooperation with an external partner. This method is installed meanwhile in all the German Federal states in cooperation of more than 10 TheoPrax agencies. A TheoPrax projects often contains a planning or statistical survey, a questionnaire, an interview. Or prototypes have to be built and tested out, manual and technical skills must be drafted. Beside the theory all senses are involved and one works in a multidiscipline field. All these factors support the learning process.

One of the main features of a TheoPrax-project is the 'real life project work'. Feeling responsible for the results requires particular attention which yields to effective learning. Linking universities, schools and industrial and business institutions with each other means that pupils learn very early working with externals rather under work conditions than under training conditions. They are better skilled for doing a good job after school and this will motivate them more. The learning outcomes refer to the theoretical, methodological, social and personal skills which are learned and used in a team during the project work. The TheoPrax method is already introduced in Brazil an Austria with great success.
\end{abstract}

\section{Introduction}

"The overriding aim of our teaching should be to try to discover and develop teaching methods through which the teachers teach less but the pupils still learn more; which result in more freedom, fun and real progress in the school and less noise, tedium and wasted effort " [1].

With these words J.A Comenius formulated a teaching principle long before the age of pedagogical reforms: freedom to learn and thereby also to learn "more".
In recent decades neuroscientists have proved what intuition and experience have been telling us for thousands of years: knowledge taught theoretically is only saved in the short-term memory of our brains, not in our long-term memory. Therefore new teaching and learning methods and teaching principles which increase learning effectiveness are needed.

Over the years many such methods have been tested and pilot schemes have also been undertaken with financial support. As soon as the financing comes to an end, however, the trials often also end, and the results are shelved. The pilot schemes rarely result in the extended research and realizable outcomes which would allow widespread introduction of successful teaching methods on a long-term basis.

In Germany a study by JuergenBaumert of the Max-Planck Institute for Educational Research in Berlin and commissioned by the National-Regional Committee for Educational Planning and Research Support (Bund-Laender-Kommissionfür Bildungsplanung und Forschungsfoerderung - BLK), led to the implementation of the SINUS project, a BLK trial programme to increase the effectiveness of the teaching of mathematics and science [2], [3].

The focus of the quality management elements for the teaching of science in this SINUS project is outlined in the following 11 modules:

- The development of a task-based learning culture;

- The "how" of scientific methods;

- The learning process which results from making errors;

- The establishment of a solid basis of scientific knowledge;

- Cumulative learning, an awareness of newlylearned skills and multidisciplinary and interdisciplinary work;

- The closing of the gender gap in science subjects;

- The development of cooperative tasks by/with pupils/students;

- The encouragement of self-directed learning

- The gathering and "how" of scientific working;

- The measurable increase of skills; 
- Quality management in schools and development of common standards for schools

The above-mentioned core quality management components are not only essential for long-term success in the teaching of science and technical subjects, they are also fundamental to all learning and to the motivation to learn.

The crucial question is "HOW"? How can and must learning content be taught so that learners are selfmotivated to learn more, so that learning content is stored in the long-term memory of the brain, and so that learning effectiveness is also improved?

Of vital importance is the interaction of brain and hand (theory and practice), but just as important is linking these to real-life solutions and applications. If these links can be achieved, motivation and learning effectiveness both increase dramatically.

The current situation in schools with regard to curricula and electives and the various challenges teachers face must also be taken into consideration. The differences in policy between the various state education authorities are also an important factor which can complicate the introduction of improved learning and teaching methods. These factors added to the declining birth-rate in our society and the increasing demand for skilled young people in industry, must all be taken into consideration in answering the "HOW?" question.

\section{The Implementation of the TheoPrax Method}

Almost 500 years after Comenius, the TheoPrax method was developed by Peter Eyerer and Dörthe Krause with the explicit aim, not just of embedding knowledge in the short-term memory, but of replacing the "spoonfeeding" of knowledge with active and self-defined learning. Furthermore, such active and self-directed learning should be project-based, carried out in cooperation with external, preferably local partners (from industry, public authorities and clubs) thereby establishing practical links with society in order to develop both subject-specific and multi-disciplinary competencies. The TheoPrax method was first introduced at the 'Fraunhofer Institute for Chemical Technology' (ICT) in Pfinztal, Germany in 1996, and since then has been implemented and continually improved, meeting with great interest from the majority of schools and universities. It has been used in all types of schools, from special needs schools, to schools for gifted pupils, integrated into the normal curriculum so that it has become a part of teachers' normal work and not an extra burden.

In introducing the method to schools, it was important for us to help students to develop a problem-solving mentality at an early stage, because as Karl Popper said, 'Life is all about problem-solving'. Related to this concept are: techniques for generating ideas; behaviors for resolving conflict in group discussions; learning from experiences; the acquisition, evaluation and selection of relevant information; the critical analysis of results; a holistic view of problems and sustainable implementation methods; a willingness to accept responsibility and to reflect upon processes; and, by applying all of the above, active stimulation of the learning process.

\section{What does the TheoPrax Method mean?}

TheoPrax is a teaching and learning method which aims to build a strong connection between schools and universities on the one hand, and industry, business and government authorities on the other. At the core of this method is the simultaneous acquisition of the required theoretical knowledge and its practical application. The TheoPrax method is based on 4 components:

1. Direct instruction for the economical transmission of factual knowledge

2. A "Teaching through Dialogue" module which aims to encourage the learner to learn actively as opposed to passively and encourages critical thinking and the questioning of accepted facts. This is carried out in the form of a teaching session in which learners, after an initial introduction to the topic, e.g. wind energy, set up a panel discussion with external experts.

3. Project-oriented group work, which is teamwork on a practical topic as an introduction to project work. This replaces parts of the direct instruction as an intermediate step before project work.

4. Real-life project work- the USP (unique selling proposition) of TheoPrax - a hands-on team project with a practical theme proposed by an external partner from business, industry, from research institutes or government authorities among others, to be carried out in supervised learning teams.

The real-life project work is explained in more detail below [4], [5].

Real-life project work is a motivating way to simultaneously acquire knowledge and know-how in a realistic setting, carried out in close cooperation with the real business world. It is the ideal link between school / university instruction, research and industry and all parties involved. The prerequisite is that the comfort zone of the school must be left behind in order for cooperation with the external partner to take place (see Figure 1). 

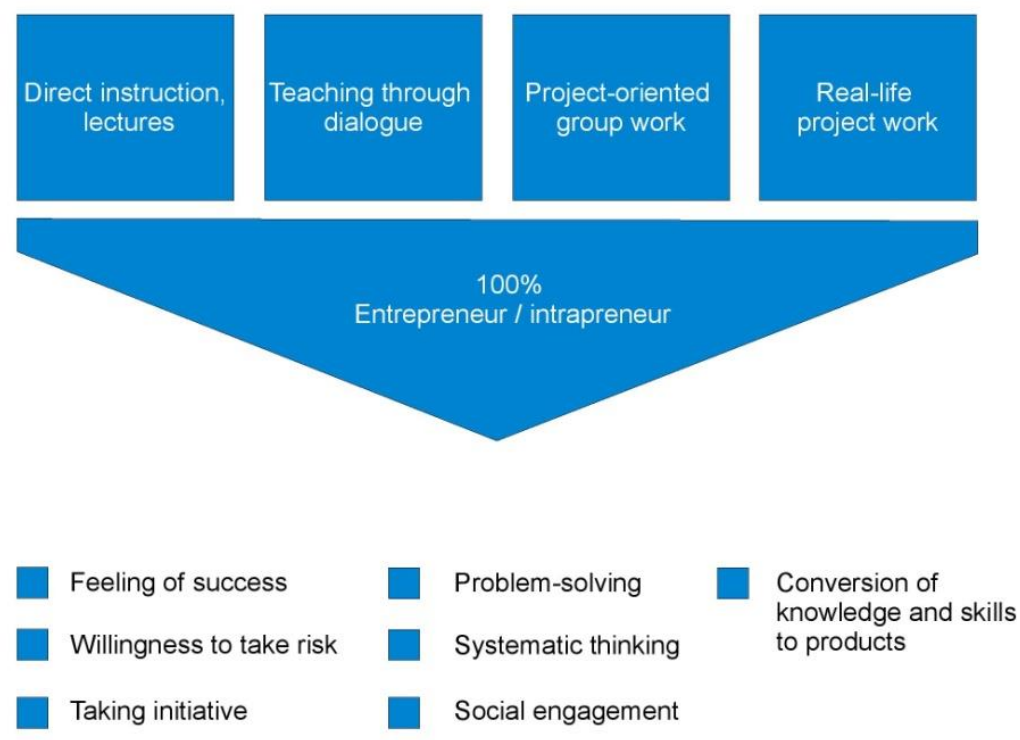

Figure. 1 Combined teaching and learning culture creates entrepreneurs

\subsection{Goals of the TheoPrax Method}

Main goal: Increase motivation to learn;

- Improve learning effectiveness;

- Practice entrepreneurial thinking and activity;

- Promote natural sciences and technology;

- Learn problem-solving working methods;

- Strengthen multi-disciplinary skills;

- Acquire knowledge in a self-directed manner;

- Improve future career perspectives;

- Link schools/universities and businesses through joint projects.

Simply put, TheoPrax real-life project work is:

\subsection{Course/study programme-integrated project work in a supervised team on industry/business- related topics commissioned on an "Offer and Order" basis}

The USP of this project, in comparison to others also mentioned by Bastian and Gudjons [6], is its "businesslike" nature, carried out on an Offer-and-Order basis. Companies, research institutes, government authorities and all types of businesses, commission projects appropriate to the level of the school or university class. These are projects which the organizations would like to realize, but for which they lack the time. Teams are formed according to interest in the topic and the degree of suitability for their course. Then the initial contact with the external partner takes place in order to confirm the goals of the project and clarify the expected project results. The students are taking their first practical steps in project management. Next they plan the project organization, make time and cost calculations and maintain regular contact with their partner, and are thus exposed to real-life aspects of the topic being learned and the related problems which can arise, outside the school environment. They prepare an offer which, when accepted by the partner, becomes a legal contract signed by both parties. This means that the client also accepts the costs involved in the planning and implementation of the project which are stated in the offer.

Although the motivation of the students usually drops during the project planning phase, it soars as soon as the order is received. Now the students are partners with responsibility and independence and they feel they are being taken seriously and treated as equals.

Experiences in Germany since 1996 and in Brazil since 2006 have been shown how effective cooperation between schools and universities and the "outside"world of industry, business and government authorities is. In these countries the skills required for training and in working life have been completely linked. Theory and practice - basic knowledge and skills are simultaneously learned and practiced.

All parties involved benefit from the projects: pupils/students through the simultaneous acquisition of theory and practice, as well as the insights they gain into new technologies and career paths, and the methods used in the working world. The employers in the business world get to know young people - their 
future customers and/or employees. Teachers have highlymotivated pupils who organize themselves, take responsibility for sourcing the information they need and expand their knowledge and skills.

\section{Typical TheoPrax Project Cycle}

TheoPrax continually seeks projects in businesses, organizations and in local government. All project themes are collected in a database and are then offered to suitable schools. Once a theme is accepted by the teacher and the class, we visit the class in order to:

- $\quad$ estimate the scope of the project with the pupils;

- divide the class into groups which work on project parts (as tasks);

- define the order of project tasks, timeline, milestones and deadlines;

- teach the basics of project management, including teamwork, communication, resources and creativity techniques.

Once the pupils are clear about what is expected of them, they become very committed to the project. They create a catalogue of questions to clarify all aspects of the project during the first visit to the client. Every student group sends an official offer via TheoPrax to the client. Once this has been accepted, a contract is signed. This is often the first real motivation for the pupils to give their best in the project. Achieving results is not just a theoretical exercise as is typical of almost all school projects. The organizations actually need and apply these results. This is the second main motivational push for the pupils. In the end the results must be deployable as the organization has invested time and money in the project. It has financial outlay for the project expenses and has taken time to support the students during the project. This is the third motivational factor. The conclusion of this process is shown in Figure 2.

The practical work can begin:

1. Brainstorming about possible methods and tools

2. Collecting detailed information about the topic. This can be done in a multidisciplinary way by contacting various experts.

3. Collecting, sorting and analyzing literature

4. Practical work

5. Documentation of all meetings, research and dead ends

Half-way through the project, all groups present their interim reports at the second meeting in the organization. They receive feedback and, if necessary, suggestions for improvement.

The remainder of the work is optimization, documentation and the preparation of their presentation. At the third meeting the results are presented to the organization.

We very often hear, even months later: "It was lots of hard work but I have learned a lot and had fun."

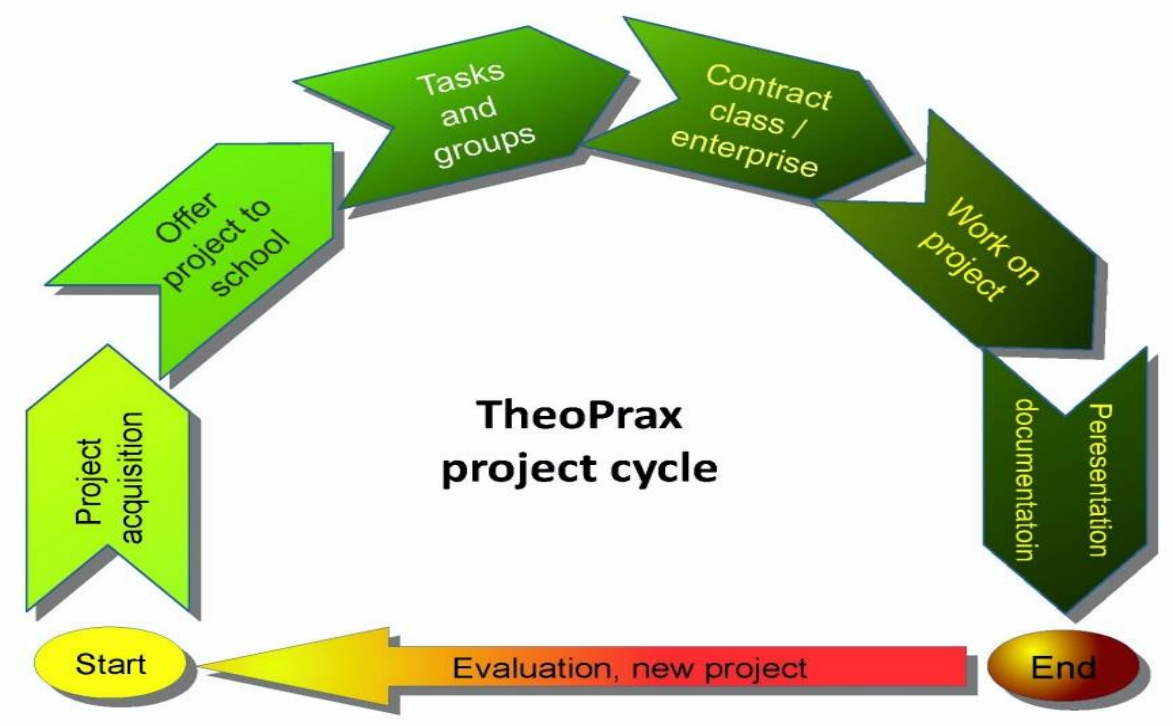

Figure 2. TheoPrax project cycle within the triangle school / university, industry and TheoPrax

This is one of the fundamental aspects of a TheoPrax project: fun and enjoyment. We engage with young people on a level playing field. The learning process is much quicker and they are learning by doing, sometimes through trial-and-error.

More than 1600 projects have been successfully carried out in Germany and Brazil. Have there been any 
failures? There have been 10 in total - not even $1 \%$ of all projects initiated. A TheoPrax project actually has 2 results: the project result, which of course is of primary importance to the client. However no less important is actually the second result - the learning outcomes! Here we refer to all project skills involved - the theoretical, methodological, social and personal skills which are learned and used in a team during the project work. What we regard as a "failure" is the termination of a project before the official end date. Regardless of the reasons, whether communication problems, bankruptcy of the company or team conflicts, the normal completion with the customary report and presentation of results is not achieved. We do not consider it a "failure" if students are unable to present their planned results, but can point out clearly why that is so, what factors were involved and what must be done to achieve these results at a later time. It is important to mention at this point that these are learning experiences which are of enormous importance for them in their later studies or working life. Each of them will, at some point, be in the situation that planned results cannot be achieved despite their best efforts because their initial assumptions were false. However these insights, when explained clearly, are also important results. Reflection on the part of the learners, together with the supervisors and clients, is therefore absolutely crucial.

It is also possible to take part in a TheoPrax project outside the normal school curriculum. This can take place at special times such as on Saturdays, or as a block of one or more days when there are no classes. These accomplishments do not receive a school grade but are rewarded with a certificate. In order that they receive suitable recognition, we make every effort to cooperate with universities and educational institutions to have modules which are equivalent in content, completely or partially accredited. This accreditation process is referred to in[7].

Table 1. Examples of past school projects

\begin{tabular}{|c|c|c|c|}
\hline Project Topic & $\begin{array}{l}\text { School } \\
\text { class }\end{array}$ & Type ofschool & Employer \\
\hline Ring test of large components & 11,12 & Highschool & RTE Akustik u. Prüftechnik \\
\hline $\begin{array}{l}\text { Homogenisation of a lubricant } \\
\text { dispersion }\end{array}$ & $10-12$ & Highschool & G.Rau GmbH Pforzheim \\
\hline $\begin{array}{l}\text { Teaching wallchart for redox flow } \\
\text { battery }\end{array}$ & 9 & Highschool & Fraunhofer ICT \\
\hline Development of drinks for Dietz & 12 & Highschool & Dietz \\
\hline $\begin{array}{l}\text { Development and construction of a } \\
\text { waffle maker as an exhibition object of } \\
\text { a science fair }\end{array}$ & 11 & Highschool & Wolfach \\
\hline $\begin{array}{l}\text { Separation of caraway seeds from the } \\
\text { seeds of weeds }\end{array}$ & 12 & Highschool & Demeter Bauer \\
\hline Safetyanalysis & $11 / 12$ & Highschool & Technologiefabrik Karlsruhe \\
\hline $\begin{array}{l}\text { Optimisation of Fischer Technik } \\
\text { construction kits }\end{array}$ & 8 & Highschool & Fischer Technik \\
\hline $\begin{array}{l}\text { Degreasing of aluminium cans in } \\
\text { production }\end{array}$ & 9 & $\begin{array}{l}\text { Secondary } \\
\text { modern School }\end{array}$ & Nussbaum \\
\hline Creative productstandardisation & 11 & Highschool & $\begin{array}{l}\text { Lackus } \\
\text { Sonderkonstruktionen }\end{array}$ \\
\hline Construction of a Flash-Over-Box & 9 & $\begin{array}{l}\text { Secondary } \\
\text { modern School }\end{array}$ & Feuerwehr Grötzingen \\
\hline Design ofrentalbicycles & 8 & $\begin{array}{l}\text { Secondary } \\
\text { modern School }\end{array}$ & Rad+Tat Karlsruhe \\
\hline
\end{tabular}




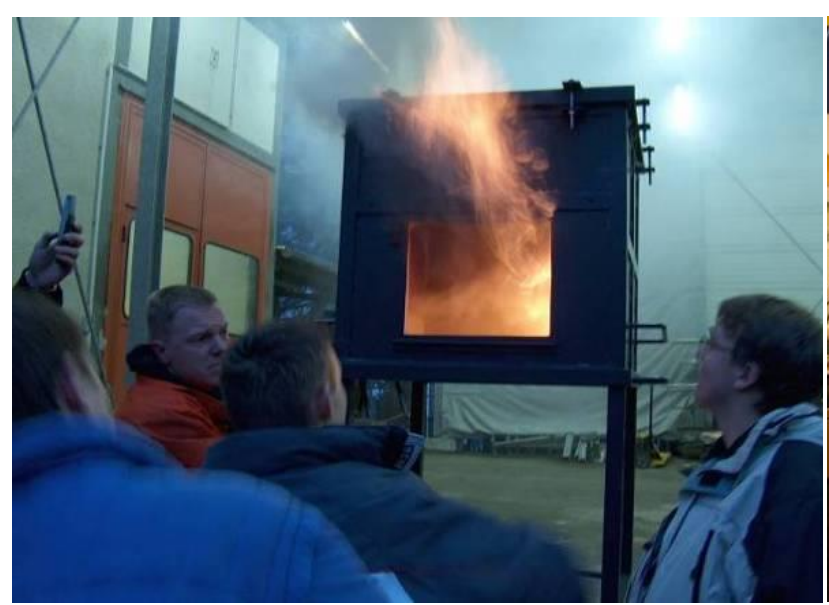

Photo 1: The Flash-Over-Box built for the Grötzingen Fire Brigade by Hauptschule pupils in action for the first time.

The TheoPrax method has now spread out across Germany from the TheoPrax Centre at the Fraunhofer ICT Institute to 14 further centers and 6 branches which support regional schools and/or universities in implementing the TheoPrax method. The TheoPrax Centre at the Fraunhofer ICT Institute and the TheoPrax Communications Centre at Furtwangen University cooperate, for example, in a federally-funded Cluster of Excellence project, the MicroTECSüdWest, which aims to introduce microsystems technology in schools and to awaken interest among young people for TheoPrax project work. The goal is to alleviate the problem of the lack of skilled employees in the field of microsystems technology.

\section{Effective learning through real life project work}

Peter Eyerer carried out the following 9-year-long study in the area of Mechanical Engineering/Plastics Technology at the University of Stuttgart:

Prior to the course he had his students fill out a questionnaire with examination questions to establish their current level of knowledge on the subject. The results showed that the students were already able to answer $18 \%$ of the exam-type questions before attending lectures. In the two-semester course the students were given lectures using a traditional teacher-centered, direct instruction approach. At the end of the course the students were asked to complete the same questionnaire with identical questions. The sobering results were that only $31 \%$ of the questions posed were answered correctly. This meant that over 2 semesters, students had only succeeded in increasing their knowledge by $13 \%$, and in the written examination which followed, the average grade achieved was only 3.3 .

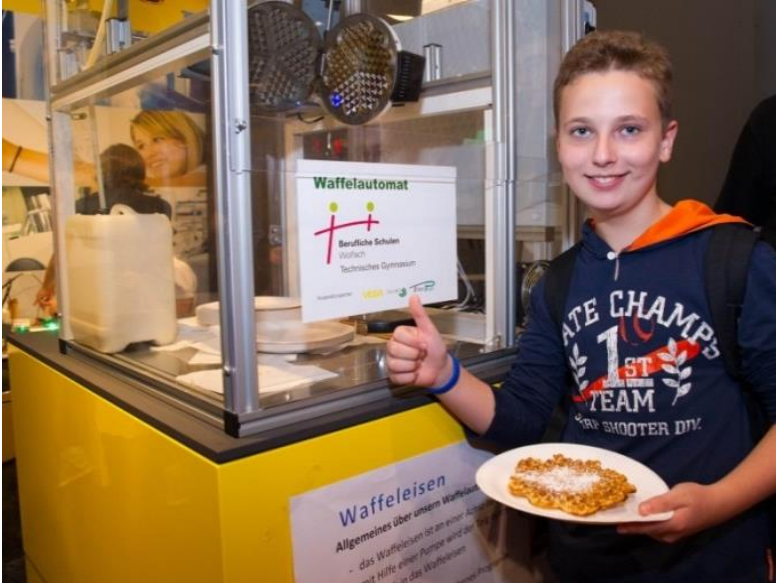

Photo 2: A fully automatically working waffle maker developed and constructed as an exhibition object by pupils of a Berufsschule for VEGA $K G$

After the introduction of the TheoPrax method (1/3 direct instruction, 1/3 project-oriented group work using the Teaching through Dialogue method - inquiry-based learning with the teacher as facilitator, and 1/3 group project work), the results of the questionnaire with identical questions and under identical conditions were as follows:

The level of knowledge of the second group prior to instruction was approximately equal to that of the first group tested in that $20 \%$ of questions were correctly answered. However, the second group achieved an end result of $47 \%$ correct answers and an average grade of 2.0. The level of their knowledge had therefore increased by $27 \%$. Furthermore they gained many key skills in the process. 8

Carl Wiemann of the University of British Columbia and Nobel prizewinner for physics carried out an independent but virtually identical study. In his 8-year study, he compared the results of 270 students who were taught by an extremely knowledgeable and experienced physics professor using the direct instruction approach, with the results of 270 students taught using a task-based approach by young, relatively inexperienced post-docs. This study showed that learning outcomes among the 270 students who were taught using the task-based teaching methods improved by a factor of 2 [8].

\section{Learning with all senses}

Any project involving external partners is by implication no longer "school" work. The comfort zone of the school must be left. This step outside the comfort zone guarantees interaction with completely different and often new factors which are not dealt with, or are only dealt with in a theoretical manner in normal school life. Furthermore most projects involve practical work 
which is necessary to achieve the planned project results. For example, in planning a statistical survey, a questionnaire is compiled or an interview is carried out. In other projects where prototypes have to be built and tests carried out, manual and technical skills are also required.

Learning with the brain and the hands (Pestalozzi) a much-described and long-demanded method of learning which guarantees the anchoring of what is learned in the long term memory through activation of all the senses. The direct instruction approach is a quick and effective way of transmitting factual knowledge. It is practically useless if it is not followed up with practical application. Experiences can be described and presented by means of direct instruction but they cannot be activated. To do this the direct instruction approach must be combined with a hands-on approach such as the TheoPrax method.

\section{The role of the teacher - a guide rather than a leader}

It is important that the division of work in the reallife project work as described in the TheoPrax method is not, as is often feared, the sole responsibility of the teachers, who may already be under pressure to implement other new reforms. Using the TheoPrax method, teachers play a completely different role in which they guide rather than lead. Their workload is not reduced but it does take a different form. The teacher is a mentor, motivator, guide, observer and initiator, a mediator, the contact for pupils and external partners, a moderator, and last but not least, is still an evaluator and assessor. The teacher has at his side the experts from the business world. He is no longer the expert, but plays an equally active role in the learning process in each project, as each of these projects is unique and not to be found in any textbook. Only the TheoPrax method itself remains the same in every project (the Offer and Order principle).

However, has this ever been learnt and practiced by teachers? Will teachers be trained for this role? On the whole, the answer in Germany is clearly NO.

The employees of the TheoPrax Centre have been running teaching courses on integrated graded project work across Germany for the last 15 years. Individual teaching modules include basic project management skills such as risk and opportunity planning, the creation of systemic maps to gain an overall perspective, and the application of various creativity techniques. These are not simply taught using the direct instruction approach, but are also, as in the TheoPrax method, tried and tested by course participants to allow them to gain first-hand experience [9].

Time and again teachers tell us in our training courses, "Now I know how the pupils feel when they don't know anything but are expected to carry out experiments or even plan a project on a particular subject. It's much easier to understand now how difficult it is for them to ask precise, specific questions and how they feel when they are being observed and assessed. This will help me to teach the subject better in the future."[10]

\section{TheoPrax - The international success story}

There has been international interest in the teachinglearning method of TheoPrax since 2006 - first in Brazil where the Vice-President of the Brazilian Ford plant at that time, the Frenchman Luc de Ferran, became involved in TheoPrax. Contrary to the situation in Germany, they immediately began to set up TheoPrax labs in Brazil, i.e. technology, chemistry and physics labs were established in various locations for independent experimentation and project work. The main organizing and financing body for industry and MINT education in Brazil is SENAI Bahia, (Servico National Aprendizagem Industrial) Sistema FIEB, Salvador de Bahia. In 2012 the first TheoPrax Centre in Salvador de Bahia was founded with 15 TheoPrax Teaching and Learning Labs and over 100 TheoPrax instructors in Bahia alone.

On 30 October 2014 the first TheoPrax Centre in Linz, Austria was opened.

The founding of the TheoPrax OÖ Communication center in Austria made possible the introduction of a new curriculum subject (beginning in the school year of 2015/2016) in the AHS senior classes. TheoPrax aims to bring real-life aspects of business into the schools and thus strengthen cooperation. TheoPrax OÖ is a joint project of the state of Upper Austria, the School Board of Upper Austria and the Education Group, in cooperation with the Fraunhofer Institute ICT.

\section{Conclusion}

Let us look once more at what Comenius wrote in the Didactica Magna.[1] "A teaching practice in which the teacher need not teach as much."

As Comenius demanded, with the TheoPrax method we halve the amount of direct instruction and double the learning effectiveness. The work required of lecturers and teachers is not less than that required using direct instruction methods, but it is different. On the contrary: particularly in the initial phase when everything is new, the amount of work involved is greater and it will remain so until the TheoPrax methods become routine. We assume that studies such as those carried out in educational institutions in British Columbia and at Stuttgart University, will show the same or similar results. Such studies have not taken place in the past due to lack of finances. Our experience shows that by using the TheoPrax method, particularly in area of the natural sciences, we generally gain motivated learners who 
willingly seek the theoretical knowledge they need in order to be able to carry out their project successfully.

In addition, all evaluations which have been made with regard to TheoPrax project work, either by our organization or by external organizations, have shown that the learning method stimulates interest, improves learning effectiveness and strengthens the skills required for the working world. It also allows young people to make more focused career and study choices, as through the practical work, they gain increased awareness of their interests, strengths and weaknesses. By using this method, learners will be motivated to acquire knowledge in order to achieve their self-defined goals and good project results.

The learning process takes place almost without the learners being aware of it, mostly realized later. Again and again we hear from former pupils: "I'll never forget the project work. I learned so much that I never learned in the classroom. Now that I am studying at University, I realize the advantages I have over the other students."

Our conviction is based on experience.

\section{The TheoPrax teaching-learning method increases learning motivation and doubles learning effectiveness}

Some final words from one of our pupils after a very successful presentation of the project team results:

"It wasn't easy. Actually, it was a lot of work and pretty stressful. But it was great fun and we learned much more than just facts. It's just a pity that we had so little time because we had to work for our other subjects, too."

\section{References}

[1] Comenius, Johann Amos, Didactica Magna 1657.

[2] Abschlussbericht zum BLK Modell-versuchsprogramm „Steigerung der Effizienz des mathematischnaturwissenschaftlichen Unterrichts, Redaktion: M. Hertrampf, Leibniz-Institut für die Pädagogik der Natur-wissenschaften (IPN), Olshausenstr. 62, 24098 Kiel, 2003.

[3] Bund-Länder-Kommission für Bildungs-planung und Forschungsförderung (Hrsg.). Gutachten zur Vorbereitung des Programms „Steigerung der Effizienz des mathematischnaturwissenschaftlichen Unterrichts“. Bonn: BLK, 1997, Heft 60 .

[4] Eyerer, P.: TheoPrax - Bausteine für Lernende Organisationen - Projektarbeit in Aus- und Weiterbildung Stuttgart: Klett-Cotta Verlag, 2000, 411 S., ISBN 3-60891012-3.

[5] Eyerer, P.; Krause, D.: Warum ist der Ernstcharakter bei der Projektarbeit so wichtig? Pädagogische Reflexionen unter
Berücksichtigung neuerer Ergebnisse der Gehirnforschung. In: Motivation zum Lernen. Tagungsband zur 10. TheoPraxTagung, 11. Oktober 2007, Fraunhofer-Institut für Chemische Technologie ICT, Pfinztal, S. 26-39, ISBN 978-3-8167-74600 .

[6] Johannes Bastian; Herbert Gudjons: Das Projektbuch. Hamburg, Bergmann + Helbig Verlag, 1994.

[7] Dörthe Krause, Safi Baborie, Peter Eyerer: Cluster MicroTEC Südwest, Verbundprojekt MicroDidact. In: Bildung für Innovationen - Innovationen in der Bildung - die Rolle durchlässiger Bildungsangebote in Clusterstrukturen. Sabine Globisch, Ernst A. Hartmann, Claudia Loroff, Ida Stamm-Riemer (Hrsg.), Waxmann Verlag, 2012, ISBN 978-38309-2622-1.

[8] Eyerer, P.; Krause, D.: Methoden-Mix erhöht die LehrLern-Effektivität und deren Effizienz. Neues Handbuch Hochschullehre Nr. 36, Raabe Verlag, März 2009

[9] Mervin, J.:A Better Way to Teach? Latest news, Science Now, 12th May, 2011.

[10] Krause, D.;Eyerer, P.: Schulprojekte managen - TheoPrax Methodik in Aus- und Weiterbildung. W. Bertelsmann Verlag, Bielefeld, Dezember 2007, ISBN 978-3-7639-3618-2. 